\title{
Weed suppression by soil steaming in combination with activating compounds
}

\author{
P BÀRBERI*, A C MOONEN*, A PERUZZI†, M FONTANELLI $† \&$ M RAFFAELLI† \\ *Land Lab, Scuola Superiore Sant'Anna, 56127 Pisa, PI, Italy, and $\dagger$ Section of Agricultural Engineering, Department of Agronomy and \\ Agroecosystem Management, University of Pisa, 56124 Pisa, PI, Italy
}

Received 23 August 2007

Revised version accepted 8 April 2008

\section{Summary}

The aim of this study was to determine the weed suppression potential of soil steaming plus activating compounds $(\mathrm{KOH}$ or $\mathrm{CaO})$ to boost soil temperature. Different combinations between the compounds and rates were tested in experiments carried out in the field and in a controlled environment. Treatment effects were assessed on field weed vegetation and on seedbank and seedling emergence of three winter (Alopecurus myosuroides, Matricaria chamomilla and Raphanus raphanistrum) and four spring annuals (Amaranthus retroflexus, Echinochloa crus-galli, Fallopia convolvulus and Setaria viridis), were assessed on field weed vegetation. Neither maximum soil temperature (from 72 to $85^{\circ} \mathrm{C}$ ) nor duration of high temperature in the $3 \mathrm{~h}$ following application consistently affected weed suppression. In the field, no significant effects on total weed density were recorded, but there were some significant effects on individual species. The weed seedbank was clearly suppressed by activated steaming: total seedling emergence was inversely related to increasing $\mathrm{KOH}$ rates both in the 0-10 and 10-20 cm soil layers, while for $\mathrm{CaO}$ the relationship was significant only in the $0-10 \mathrm{~cm}$ layer. Winter annuals were more sensitive to $\mathrm{KOH}$ than $\mathrm{CaO}$ and spring annuals had a more pronounced species-specific response to treatments. There was a strong negative relationship between compound rate and seedling emergence for all species. Alopecurus myosuroides was the most sensitive to the steam-alone treatment (77\% reduction), whereas $M$. chamomilla and E. crusgalli were the least sensitive. Results from this study indicate that the type and rates of activating compounds for soil steaming must be adjusted to the weed community composition.

Keywords: integrated weed management, soil disinfection, methyl bromide substitutes, non-chemical weed control, preventive methods, weed seedbank.

Bàrberi P, Moonen AC, Peruzzi A, Fontanelli M \& Raffaelli M (2009). Weed suppression by soil steaming in combination with activating compounds. Weed Research 49, 55-66.

\section{Introduction}

Growing societal attention for environmental protection and food safety and the phasing out of methyl-bromide has stimulated research into alternative methods for soil disinfection. Solarisation is a viable alternative in Mediterranean and tropical areas (Sauerborn et al., 1989; Kumar et al., 1993). However, besides its limited use (just in summer months), soil solarisation subtracts vast areas from production for periods up to 3 months (Ricci et al., 1999). Moreover, radiation intensity and the consequent soil temperature increase to a maximum of $55^{\circ} \mathrm{C}$ at 5 to $10 \mathrm{~cm}$ depth for 40 days (an increase of up to $11^{\circ} \mathrm{C}$ with respect to the non-solarised soil) (Ahmad et al., 1996; Habeeburrahman \& Hosmani, 1996; Arora \& Yaduraju, 1998) are often insufficient to guarantee good results.

The limits of soil solarisation can be overcome by the use of hot steam, a common practice in greenhouse horticulture, but not yet adapted to large-scale field application. With soil steaming, temperatures of up to $100^{\circ} \mathrm{C}$ have been registered for about $10 \mathrm{~min}$ at $15 \mathrm{~cm}$ depth, after which temperature gradually decreased to $40^{\circ} \mathrm{C}$ (Raffaelli et al., 2002). 
Although steam does not leave any residues, high temperatures can change the physical and chemical characteristics of the soil, causing the formation of toxic substances, e.g. salt accumulation and ammonia formation (Triolo \& D'Errico, 2002). Another disadvantage of soil steaming is its non-selectivity, because steaming can also kill the beneficial soil microflora (e.g. nitrifying bacteria, antagonists of soil pathogens and mycorrhizal fungi), thus upsetting the soil ecosystem equilibrium. Alternatively, steaming can be performed at lower temperatures $\left(c .70^{\circ} \mathrm{C}\right)$ by including air in the steam stream. A temperature range from 45 to $75^{\circ} \mathrm{C}$ for $30 \mathrm{~min}$ is considered sufficient to control nematodes, most bacterial and fungal pathogens and weed seeds in a single treatment (Triolo \& D'Errico, 2002).

For application in the open field, fixed tubes used for steaming in protected environments must be replaced by a machine that injects steam into the soil. While in the case of the fixed-tube system, temperature and duration of the treatment can easily be controlled, in the open field they are dependent on initial soil temperature, moisture and particle size (Melander \& Jørgensen, 2005). Only the forward speed of the machine can regulate steaming duration (Tesi, 2001). Therefore, any technical solution increasing the amount of heat released or maintaining high soil temperatures for a longer period is potentially able to increase the effect of steaming. Activating compounds like soil-incorporated fertilisers or amendments can boost soil temperature through a hydration reaction and prolong its duration. These compounds should have low environmental impact and possibly positive side-effects, e.g. the correction of anomalous soil $\mathrm{pH}$ values or the addition of nutrients, thus buffering the negative aspects that steam may cause. The use of a polyethylene soil-mulching film laid down just after steaming can also increase the duration of high soil temperature (Habeeburrahman \& Hosmani, 1996; Chase et al., 1999).

In this study, the machine used for soil steaming was developed by Celli S.p.A. (Forlì, Italy) in collaboration with DAGA, University of Pisa. All operations (distribution and incorporation in soil of the activating compound, steam injection down to $20 \mathrm{~cm}$ depth, and placement of the plastic mulch film) are carried out in just one pass (Bàrberi et al., 2002; Peruzzi et al., 2002). The effect of two activating compounds, potassium hydroxide $(\mathrm{KOH})$ and calcium oxide $(\mathrm{CaO})$, was tested. Both have a low environmental impact and may positively affect soil nutrient status and $\mathrm{pH}$. Following a preliminary field experiment carried out in the spring of 2000, which showed that steaming with a low dose of activating compound (up to $1000 \mathrm{~kg} \mathrm{ha}^{-1} \mathrm{CaO}$ or $\mathrm{KOH}$ ), with or without a polyethylene cover, did not significantly decrease weed density in lettuce (A. Peruzzi and M. Raffaelli, unpubl. obs.), a new set of experiments was planned both under field conditions and in controlled environment.

We hypothesised that the weed suppression capacity of a specially developed soil steaming machine (Bioflash System ${ }^{\mathrm{TM}}$ ) increases with increasing doses of activating compounds, with and without soil cover. We then tested the effect of increasing doses of $\mathrm{CaO}$ and $\mathrm{KOH}$ on suppression of the total weed seedbank and on the emergence of seven weed species common in central Italy.

\section{Materials and methods}

\section{Experimental designs and samplings}

The field experiment was carried out in the autumn of 2000 on a sandy soil with $91.4 \%$ sand, $4.0 \%$ silt, $4.6 \%$ clay (USDA classification) at the Centro Interdipartimentale di Ricerche Agro-Ambientali (CIRAA) 'E. Avanzi' of the University of Pisa at S. Piero a Grado, central Italy $\left(43^{\circ} 40^{\prime} \mathrm{N} ; 10^{\circ} 19^{\prime} \mathrm{E}\right)$. Soil steaming was performed on 23 October 2000. Characteristics of soil steaming with the Bioflash System ${ }^{\mathrm{TM}}$ can be found in Peruzzi et al. (2002, 2007). Initial soil humidity and temperature were $3 \%$ and $21{ }^{\circ} \mathrm{C}$ respectively. Just before treatment, the seedbed was carefully prepared to ensure maximum smoothness of the soil surface to increase the steaming effect. No crop was sown after soil steaming. The 2000-2001 winter was characterised by particularly high autumn precipitation, low spring precipitation and relatively high temperatures. The experimental layout followed a factorial combination (split-split-plot design) between two soil cover treatments (bare soil vs. black polyethylene film laid down on the soil straight after steam injection) in the main plots, two activating compounds $(\mathrm{KOH}$ vs. $\mathrm{CaO})$ in the sub-plots and five rates of these compounds $(0,1000,2000,3000$ and $\left.4000 \mathrm{~kg} \mathrm{ha}^{-1}\right)$ in the sub-sub-plots, giving a total of 20 treatments replicated six times in plots of $1.2 \mathrm{~m}$ width by $5 \mathrm{~m}$ length. Two control treatments were added to the non-steamed plots, one with and the other without the black polyethylene film cover. The day after soil steaming, just after removal of the mulch film, the soil was sampled for weed seedbank analysis. Three soil cores of $20 \mathrm{~cm}$ depth were taken in each plot with a $3.5 \mathrm{~cm}$ diameter manual steel probe and immediately sub-divided into 0-10 and 10-20 cm sub-samples for the assessment of steaming effect on seeds located at different depths. The weed seedbank was analysed with the seedling emergence technique (Bàrberi \& Lo Cascio, 2001) during a 6 month period in a semi-open glasshouse, as described in Moonen and Bàrberi (2004). Emerged weed seedlings were periodically identified, 
counted and then removed. Seedling identification was based on Hanf (1990) and Viggiani and Angelini (1998). Actual weed infestation in the field was measured by counts in two fixed $1 \times 0.5 \mathrm{~m}$ quadrats per plot carried out 2, 4, 6, 10, 14 and 19 weeks after steaming (T1 to T6; 10 and 23 November 2000, 8 December 2000, 5 January 2001, 8 February 2001 and 15 March 2001 respectively).

The controlled environment experiment was carried out in May 2003 at CIRAA and DAGA, University of Pisa. Treatments were applied in $30 \mathrm{~cm}$ square plastic containers with parallelepiped shape and height of $50 \mathrm{~cm}$, in which steam was injected at a depth of $15 \mathrm{~cm}$ by means of a specific dispenser. The amount of steam injected was the same as that used for field treatments (Peruzzi et al., 2002, 2004). Effects of steaming were evaluated on weed seeds of three winter annuals (Alopecurus myosuroides Hudson, Matricaria chamomilla L. and Raphanus raphanistrum L.) and four spring annuals [Amaranthus retroflexus L., Echinochloa crusgalli (L.) P. Beauv., Fallopia convolvulus L. and Setaria viridis L.]. The experimental layout consisted of a factorial combination (two-way completely randomised design) of two activating compounds ( $\mathrm{KOH}$ vs. $\mathrm{CaO})$ and four compound rates $(1000,2000,3000$ and $4000 \mathrm{~kg} \mathrm{ha}^{-1}$ ), compared with the steam-only and an untreated control and replicated four times. The activating compounds were mixed with sandy soil to $15 \mathrm{~cm}$ depth, while weed seeds were put in permeable small plastic bags (100 seeds $250 \mathrm{~cm}^{-3}$ soil) resistant to high temperature and chemical damage, that were placed at $7.5 \mathrm{~cm}$ depth. After steaming, the soil and seeds present in the bags was put in plastic tubs $(14 \times 10.5 \times 4.5 \mathrm{~cm})$ in an open glasshouse. Tubs were watered and monitored daily, until (after 40 days) no further seedling emergence occurred.

Soil temperature was monitored at $15 \mathrm{~cm}$ depth in the field trial and at $7.5 \mathrm{~cm}$ depth in the controlled environment trial by means of PT100 sensors (CEAM control equipment, Empoli, Italy) $4 \mathrm{~cm}$ long that sent a voltage signal to data loggers. Temperatures were measured just at the end of the soil steaming treatments and throughout the next $180 \mathrm{~min}$. Values were then allocated to four temperature intervals $\left(<40^{\circ} \mathrm{C}\right.$; $40 \leq$ temperature $<60^{\circ} \mathrm{C} ; \quad 60 \leq$ temperature $<80^{\circ} \mathrm{C}$; $\geq 80^{\circ} \mathrm{C}$ ). Persistence of soil temperature in each of the four intervals and the highest and final (after $180 \mathrm{~min}$ ) temperature values were calculated to compare the effects of different treatments.

\section{Data analysis}

The parameters used for statistical analyses were: (a) weed density, species richness and percentage density reduction with respect to the 'true' control plots at each of the six sampling dates in the field experiment; (b) total weed seedling density emerged from the seedbank at $0-10$ and $10-20 \mathrm{~cm}$ depths in the field seedbank experiment; and (c) total seedling density by weed species and per cent density reduction with respect to the control in the controlled environment experiment. Seedbank and field weed density and weed biomass subsamples taken in each plot were aggregated and thus considered as replicates. These data and species richness were expressed per square metre. Total and individual weed species densities in the seedbank and field and per cent reduction with respect to the 'true' control plots were square-root-transformed to obtain homogeneous error variances.

Analysis of variance for split-split-plot designs was performed with CoSTat (COHORT Software, 2002), on transformed data when necessary. Analysis of variance for a split-plot design was performed on square-roottransformed field weed density data and on non-transformed seedbank densities of the $0-10$ and $10-20 \mathrm{~cm}$ layers (field experiment) to test the effect of the control treatments without activating compound but with or without soil cover and steam.

In the controlled environment experiment, weed density by species was expressed as percentage of initial seeds that germinated and analysed by two different series of ANOVA: (i) a completely randomised design to compare the nine different treatments with the untreated control, and (ii) a two-way completely randomised design to evaluate the effect of the two different activating compounds at the four rates. Differences between treatment mean values were compared using an LSD test at the 5\% significance level, as derived from the appropriate SEDs (Gomez \& Gomez, 1984). In the case of data transformation, SEDs and LSDs were calculated on transformed data and back-transformed data are presented in parentheses. Linear regression analysis was performed on total weed seedling emergence from the two soil layers (field experiment) and on individual species emergence (controlled environment experiment) as related to increasing rates of activating compounds.

\section{Results}

\section{Soil temperature}

In the field experiment, the maximum soil temperature was $75^{\circ} \mathrm{C}$ in the steam-alone treatment and always $>80^{\circ} \mathrm{C}$ in all other treatments (Table 1). Application of $\mathrm{CaO}$ at the highest rate $\left(4000 \mathrm{~kg} \mathrm{ha}^{-1}\right)$ resulted in the highest peak and final temperature $\left(85\right.$ and $42^{\circ} \mathrm{C}$ respectively) and in higher duration at high values, always $>40^{\circ} \mathrm{C}$ in the $3 \mathrm{~h}$ following soil steaming. These 


\begin{tabular}{|c|c|c|c|c|c|}
\hline \multirow{2}{*}{$\begin{array}{l}\text { Soil } \\
\text { temperature } \\
\text { (T) }\end{array}$} & \multicolumn{5}{|c|}{ Treatment } \\
\hline & $\begin{array}{l}\text { Steam } \\
\text { alone }\end{array}$ & $\begin{array}{l}\text { Steam + KOH } \\
1000\end{array}$ & $\begin{array}{l}\text { Steam + KOH } \\
4000\end{array}$ & $\begin{array}{l}\text { Steam + } \mathrm{CaO} \\
1000\end{array}$ & $\begin{array}{l}\text { Steam + } \mathrm{CaO} \\
4000\end{array}$ \\
\hline \multicolumn{6}{|c|}{ Field experiment (15 cm depth) } \\
\hline$T \max \left({ }^{\circ} \mathrm{C}\right)$ & 75 & 80 & 81 & 80 & 85 \\
\hline $\begin{array}{l}T \text { after } \\
180 \min \left({ }^{\circ} \mathrm{C}\right)\end{array}$ & 37 & 41 & 40 & 39 & 42 \\
\hline$T<40$ (min) & 58 & 0 & 0 & 19 & 0 \\
\hline T 40-60 (min) & 103 & 159 & 151 & 137 & 148 \\
\hline T 60-80 (min) & 19 & 17 & 24 & 19 & 25 \\
\hline$T>80$ (min) & 0 & 4 & 5 & 5 & 7 \\
\hline \multicolumn{6}{|c|}{ Controlled environment experiment (7.5 cm depth) } \\
\hline$T \max \left({ }^{\circ} \mathrm{C}\right)$ & 46 & 50 & 57 & 57 & 72 \\
\hline $\begin{array}{l}T \text { after } \\
180 \min \left({ }^{\circ} \mathrm{C}\right)\end{array}$ & 44 & 45 & 48 & 45 & 47 \\
\hline$T<40$ (min) & 10 & 0 & 0 & 0 & 0 \\
\hline T 40-60 (min) & 170 & 180 & 178 & 177 & 130 \\
\hline T 60-80 (min) & 0 & 0 & 2 & 3 & 50 \\
\hline$T>80$ (min) & 0 & 0 & 0 & 0 & 0 \\
\hline
\end{tabular}

Table 1 Maximum soil temperature, temperature after $180 \mathrm{~min}$. and average duration of soil temperature in different intervals after treatment with steam alone or in combination with an activating compound $(\mathrm{KOH}$ or $\mathrm{CaO})$ applied at 1000 or $4000 \mathrm{~kg} \mathrm{ha}^{-1}$ in the field experiment (steaming date: 23 October 2000) and in the controlled environment experiment (steaming date: 21 May 2003) differences were even more pronounced in the controlled environment experiment, where maximum soil temperature (at $7.5 \mathrm{~cm}$ depth) ranged between 46 and $72^{\circ} \mathrm{C}$, whereas final temperature ranged between 44 and $48^{\circ} \mathrm{C}$. $\mathrm{CaO}$ at $4000 \mathrm{~kg} \mathrm{ha}^{-1}$ was the best treatment to boost the exothermic reaction in soil, as soil temperature remained in the 60 to $80^{\circ} \mathrm{C}$ interval for $28 \%$ of the time in the $3 \mathrm{~h}$ following application (Table 1).

\section{Field experiment: effect on actual weed vegetation}

The total number of weed species recorded at the six sampling dates (T1 to T6; 2, 4, 6, 10, 14 and 19 weeks after steaming respectively) increased from 10 to 21 , and mean species richness increased from $2.7 \mathrm{~m}^{-2}$ at $\mathrm{T} 1$ to $5.2 \mathrm{~m}^{-2}$ at T6. Overall, four species contributed more than $96 \%$ to total weed density at all sampling dates: Veronica hederifolia L. (46\%), Capsella bursa-pastoris (L.) Medicus (27\%), Lamium purpureum L. (24\%) and Lilium spp. (3\%). Of these, only L. purpureum was absent at $\mathrm{T} 1$.

No significant treatment effects on species richness, other than an activating compound by mulch interaction at T2 and an application rate effect at T3, were found. However, these effects were inconsistent. No significant differences in weed density between the control and steam-alone treatments, with or without black plastic mulch were found. Mean weed density per plot doubled from $\mathrm{T} 1$ to $\mathrm{T} 2$ ( 74 to 148 plants $\mathrm{m}^{-2}$ ) and then fluctuated slightly from T2 to T6. None of the sampling date treatment combinations resulted in a significant decrease in total weed density with respect to the control plots. Mean reductions in weed density for the six sampling dates were: $36 \%$ and $29 \%$ with and without black plastic mulch film; and $37 \%$ and $31 \%$ using $\mathrm{CaO}$ and $\mathrm{KOH}$; and $24 \%, 39 \%, 35 \%, 29 \%$ and $32 \%$ using $0,1000,2000,3000$ and $4000 \mathrm{~kg} \mathrm{ha}^{-1}$ of activating compounds respectively.

Treatments never had an effect on Lilium spp. density. C. bursa-pastoris density was reduced significantly with increasing activating compound rate at $\mathrm{T} 4$ (stronger effect of $\mathrm{CaO}$ ) and an application rate by cover interaction at T6 was found (data not shown). At T2, activating compound and application rate showed a significant effect on L. purpureum density and from T3 to T6 there was an interaction between activating compound and application rate for which density of this species decreased using $\mathrm{CaO}$ at 1000 and $2000 \mathrm{~kg} \mathrm{ha}^{-1}$ and increased with respect to the control treatment at the higher compound rates, while it increased with increasing $\mathrm{KOH}$ rates (Table 2). For $V$. hederifolia there was a significant effect of application rate from $\mathrm{T} 1$ to $\mathrm{T} 5$, of activating compound at T5 and of the activating compound by application rate interaction at T6 (stronger effect of $\mathrm{KOH}$, data not shown). At $\mathrm{T} 1$, the highest application rate $\left(4000 \mathrm{~kg} \mathrm{ha}^{-1}\right)$ reduced $V$. hederifolia density by $60 \%$, while from T2 to T6 all rates (averaged over activating compounds) reduced $V$. hederifolia density with respect to the steam-alone treatment (on average, by $35 \%, 36 \%, 45 \%, 40 \%$ and $31 \%$ respectively) (Table 3).

\section{Field experiment: effect on the weed seedbank}

The total density of weed seedlings emerging from the $0-10 \mathrm{~cm}$ soil layer was not affected by any of the four control treatments without activating compound. The mean number of total seedlings emerging from the plots without or with steam treatment was 4417 and 
Table 2 Effect of activating compound $\times$ rate interaction on squareroot transformed field density of Lamium purpureum (back-transformed mean values are shown in parentheses) across five sampling dates

\begin{tabular}{|c|c|c|c|c|c|c|}
\hline \multirow[b]{2}{*}{ Compound } & \multirow{2}{*}{$\begin{array}{l}\text { Rate } \\
\left(\mathrm{kg} \mathrm{ha}^{-1}\right)\end{array}$} & \multicolumn{5}{|c|}{ Weeks after steaming } \\
\hline & & 4 & 6 & 10 & 14 & 19 \\
\hline \multicolumn{7}{|c|}{ L. purpureum density (plants $\mathrm{m}^{-2}$ ) } \\
\hline \multirow[t]{5}{*}{$\mathrm{CaO}$} & 0 & $4.1(16)$ & $5.5(31)$ & $5.3(28)$ & $5.4(29)$ & $4.4(20)$ \\
\hline & 1000 & $3.4(11)$ & $4.9(24)$ & $4.3(19)$ & $4.6(21)$ & $3.8(14)$ \\
\hline & 2000 & $3.2(10)$ & 4.4 (19) & $4.0(16)$ & $4.4(19)$ & $3.9(16)$ \\
\hline & 3000 & $4.3(18)$ & $5.6(32)$ & $5.1(26)$ & $5.4(29)$ & $4.7(22)$ \\
\hline & 4000 & $4.5(20)$ & $6.7(45)$ & $5.8(34)$ & $6.2(38)$ & $4.8(23)$ \\
\hline \multirow[t]{6}{*}{$\mathrm{KOH}$} & 0 & $4.1(16)$ & $5.5(31)$ & $5.3(28)$ & $5.4(29)$ & $4.4(20)$ \\
\hline & 1000 & $5.4(29)$ & $7.2(52)$ & $6.5(42)$ & $6.9(47)$ & $5.7(32)$ \\
\hline & 2000 & $5.9(35)$ & $8.3(69)$ & $8.3(68)$ & $7.9(62)$ & $7.3(53)$ \\
\hline & 3000 & $6.4(41)$ & $9.2(84)$ & $8.6(73)$ & 8.7 (75) & $7.3(51)$ \\
\hline & 4000 & $6.4(41)$ & $8.6(73)$ & $7.9(63)$ & $8.4(71)$ & $7.3(53)$ \\
\hline & SED (d.f. $=80$ ) & NS & $0.97^{*}$ & $0.88^{*}$ & $0.87^{*}$ & $0.71^{*}$ \\
\hline
\end{tabular}

NS, not significant.

*Significant at $P<0.05$ ( $F$-test).

\begin{tabular}{lllllll}
\hline \multicolumn{7}{c}{ Weeks after steaming } \\
\cline { 2 - 7 } Rate $\left(\mathrm{kg} \mathrm{ha}^{-1}\right)$ & 2 & 4 & 6 & 10 & 14 & 19 \\
\hline \multicolumn{2}{l}{ V. hederifolia density (plants $\mathrm{m}^{-2}$ ) } & & & & \\
0 & $4.4(20)$ & $8.4(71)$ & $9.6(92)$ & $10.8(116)$ & $11.5(133)$ & $9.6(91)$ \\
1000 & $3.8(15)$ & $7.0(49)$ & $8.1(65)$ & $8.0(64)$ & $9.2(84)$ & $7.9(63)$ \\
2000 & $3.9(15)$ & $6.8(46)$ & $7.5(56)$ & $7.7(60)$ & $8.7(76)$ & $7.8(61)$ \\
3000 & $4.0(16)$ & $6.9(47)$ & $7.7(59)$ & $8.3(68)$ & $9.1(83)$ & $8.1(66)$ \\
4000 & $2.9(8)$ & $6.5(43)$ & $7.4(55)$ & $7.9(62)$ & $9.0(81)$ & $7.8(61)$ \\
SED (d.f. $=80)$ & $0.36^{* *}$ & $0.52^{*}$ & $0.58^{*}$ & $0.68^{* *}$ & $0.64^{*}$ & $0.47^{*}$ \\
\hline
\end{tabular}

* and **Significant at $P<0.05$ and 0.01 respectively $(F$-test).
Table 3 Effect of application rate (averaged over two activating compounds) on square-root transformed field density of Veronica hederifolia (back-transformed mean values are shown in parentheses) across six sampling dates
Figure 1 shows the relationships between $\mathrm{KOH}$ and $\mathrm{CaO}$ application rate and total weed seedling emergence from the two soil layers. In the $0-10 \mathrm{~cm}$ layer, the relationship was significant for both compounds $\left(r^{2}=0.98\right.$ and 0.89 for $\mathrm{KOH}$ and $\mathrm{CaO}$ respectively), while in the $10-20 \mathrm{~cm}$ layer it was significant only for $\mathrm{KOH}$ and not for $\mathrm{CaO}\left(r^{2}=0.87\right.$ and 0.31 respectively). In the $0-10 \mathrm{~cm}$ layer, application of the highest rate of $\mathrm{KOH}$ resulted in a $76 \%$ reduction in total weed seedling density compared with the steam-alone treatment, while the maximum reduction achieved with the highest rate of $\mathrm{CaO}$ was $20 \%$ ( $>3000$ seedlings $\mathrm{m}^{-2}$ still emerged). The regression equations show that for any additional $100 \mathrm{~kg} \mathrm{ha}^{-1}$ of activating compound used, $\mathrm{KOH}$ caused a reduction of 58 seedlings $\mathrm{m}^{-2}$ more than $\mathrm{CaO}$. In the 10-20 cm layer, the highest rate of $\mathrm{KOH}$ was able to reduce total weed emergence by $55 \%$
Table 4 Effect of activating compound $\times$ rate interaction on squareroot transformed total weed emergence from the $0-10 \mathrm{~cm}$ soil layer (backtransformed mean values, as seedlings $\mathrm{m}^{-2}$, are shown in parentheses)

\begin{tabular}{llllll}
\hline & \multicolumn{6}{l}{ Total seedbank - rate $\left(\mathrm{kg} \mathrm{ha}^{-1}\right)$} \\
\cline { 2 - 6 } Compound & 0 & 1000 & 2000 & 3000 & 4000 \\
\hline $\mathrm{CaO}$ & $60.8(3694)$ & $58.4(3412)$ & $59.3(3515)$ & $57.9(3358)$ & $53.9(2904)$ \\
$\mathrm{KOH}$ & $60.8(3694)$ & $57.8(3344)$ & $48.6(2358)$ & $41.3(1708)$ & $27.0(728)$ \\
SED (d.f. $=80)$ & $4.72^{* *}$ & & & & \\
\hline
\end{tabular}

*** Significant at $P<0.001$ ( $F$-test). 

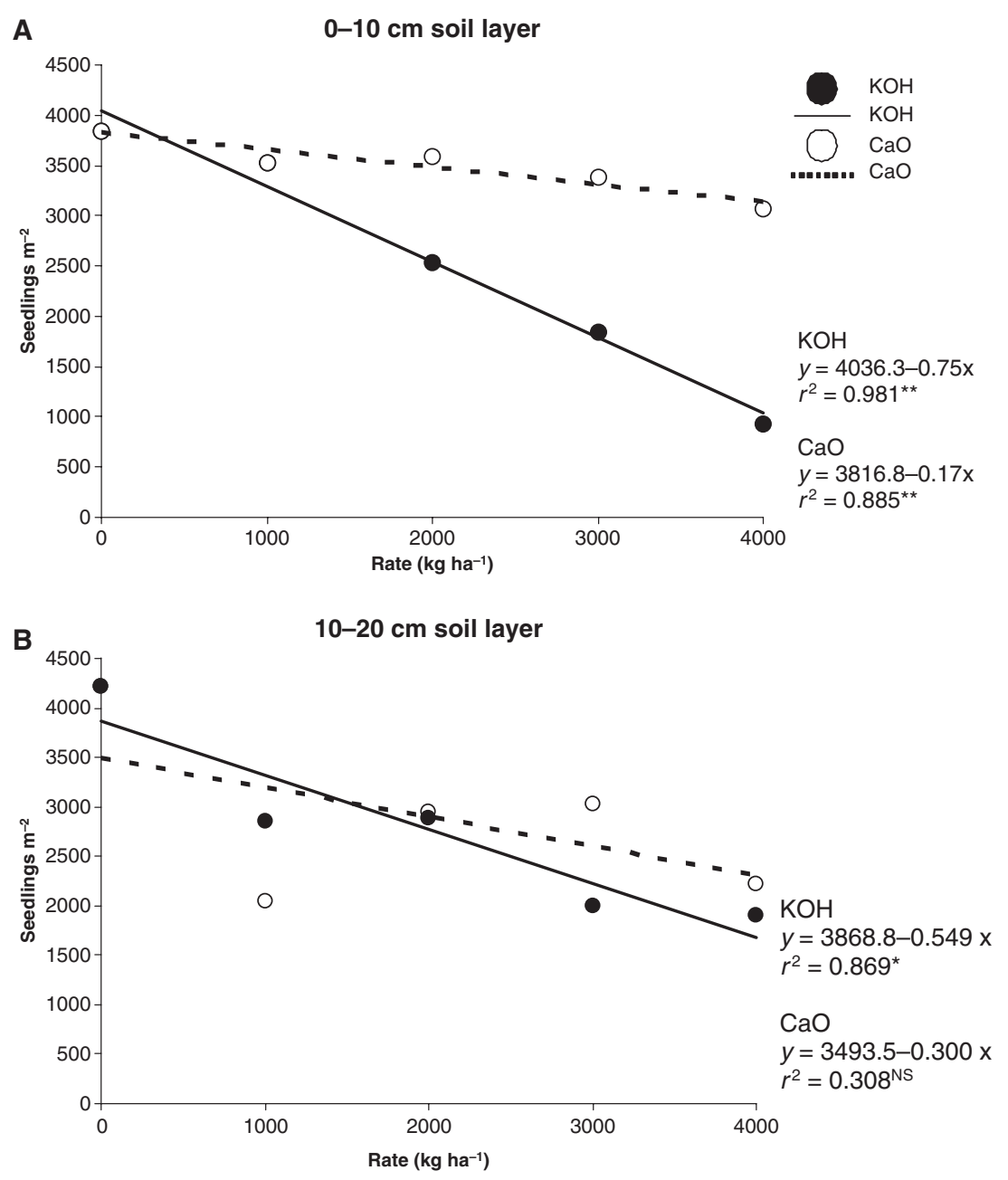

Fig. 1 Regression lines of total weed seedlings emergence from the $0-10 \mathrm{~cm}$ (A) and $10-20 \mathrm{~cm}$ (B) soil layers on activating compound $(\mathrm{KOH}$ or $\mathrm{CaO})$ rate, and corresponding equations and $r^{2}$ values. NS, not significant; $*$ and $* *$ significant at $P<0.05$ and 0.01 respectively. compared with the steam-alone treatment, whereas $\mathrm{CaO}$ rates had inconsistent effects on emergence.

A total of 19 and 15 weed species were recorded in the 0-10 and 10-20 cm layers respectively. Seven species, each with a relative abundance $>1 \%$, accounted for at least $96 \%$ of the total weed seedbank in the two layers: C. bursa-pastoris $(60 \%$ and $59 \%)$, L. purpureum $(12 \%$ and $14 \%), V$. hederifolia $(9 \%$ and $11 \%)$, P. oleracea $(8 \%$ in each layer), Sonchus spp. (3\% and 1\%), C. album (1\% in each layer) and Poa spp. (1\% and 2\%).

In the $0-10 \mathrm{~cm}$ layer, seedling densities showed a compound by application rate interaction for C. bursapastoris and a significant compound effect on $V$. hederifolia $(32 \%$ reduction for $\mathrm{CaO}$ vs. $80 \%$ reduction for $\mathrm{KOH}$ with respect to the steam alone treatment), whereas L. purpureum and P. oleracea (on average, 191 and 99 seedlings $\mathrm{m}^{-2}$ respectively) were not influenced by any of the treatments. Increasing rates of $\mathrm{CaO}$ had no effect on seedling density of $C$. bursa-pastoris, while an application rate of $2000 \mathrm{~kg} \mathrm{ha}^{-1} \mathrm{KOH}$ already significantly reduced seedling density with respect to the steam-alone treatment. This effect was stronger with increasing application rates $(87 \%$ reduction at
$4000 \mathrm{~kg} \mathrm{KOH} \mathrm{ha}{ }^{-1}$ ). In the $10-20 \mathrm{~cm}$ layer, seedling density of C. bursa-pastoris, L. purpureum and $V$. hederifolia was lower where an activating compound was used, independent of the type of compound, and it was almost significant $(P<0.10)$ for $P$. oleracea (data not shown). Any compound rate significantly decreased seedling densities of all four species with respect to the steam-alone treatment, except for the $2000 \mathrm{~kg} \mathrm{ha}^{-1}$ rate in the case of $C$. bursa-pastoris.

\section{Controlled environment experiment}

Compared with the control, the steam-alone treatment reduced $(P<0.05)$ seedling emergence of $A$. myosuroides, $F$. convolvulus and $S$. viridis (by $77 \%, 44 \%$ and $39 \%$ respectively), whereas it was not effective on M. chamomilla, $R$. raphanistrum, A. retroflexus and E. crus-galli (Table 5). Addition of an activating compound decreased weed seedling emergence in all species, with the only exception of E. crus-galli when both compounds were used at the lowest rate.

In general, winter annuals showed a higher sensitivity to $\mathrm{KOH}$ than to $\mathrm{CaO}$, with emergence reductions from 
Table 5 Final percentage seedling emergence of the seven weed species after soil steaming with addition of two activating compounds (KOH and $\mathrm{CaO}$ ) at four rates (1000 to $\left.4000 \mathrm{~kg} \mathrm{ha}^{-1}\right)$ as compared to the steam-alone treatment and the untreated control in the controlled environment experiment

\begin{tabular}{|c|c|c|c|c|c|c|c|}
\hline Treatment & $\begin{array}{l}\text { ALOMY } \\
\text { (d.f. }=24)\end{array}$ & $\begin{array}{l}\text { MATCH } \\
\text { (d.f. }=24)\end{array}$ & $\begin{array}{l}\text { RAPRA } \\
\text { (d.f. }=24)\end{array}$ & $\begin{array}{l}\text { AMARE } \\
\text { (d.f. }=27)\end{array}$ & $\begin{array}{l}\text { ECHCG } \\
\text { (d.f. }=27 \text { ) }\end{array}$ & $\begin{array}{l}\text { POLCO } \\
\text { (d.f. }=27)\end{array}$ & $\begin{array}{l}\text { SETVI } \\
\text { (d.f. }=27 \text { ) }\end{array}$ \\
\hline Control & 77.0 & 82.0 & 87.0 & 69.8 & 89.5 & 83.0 & 80.3 \\
\hline Steam alone & 17.5 & 91.0 & 90.3 & 59.8 & 78.0 & 46.5 & 49.3 \\
\hline KOH 1000 & 10.8 & 37.0 & 24.0 & 50.0 & 74.0 & 26.8 & 39.5 \\
\hline KOH 2000 & 8.8 & 23.0 & 10.5 & 27.0 & 56.0 & 22.8 & 34.0 \\
\hline KOH 3000 & 5.5 & 11.0 & 8.8 & 25.0 & 49.8 & 18.8 & 28.8 \\
\hline $\mathrm{KOH} 4000$ & 4.0 & 3.3 & 6.0 & 22.5 & 17.5 & 14.5 & 21.8 \\
\hline $\mathrm{CaO} 1000$ & 15.8 & 49.3 & 41.3 & 23.5 & 73.3 & 26.5 & 42.8 \\
\hline CaO 2000 & 12.3 & 44.5 & 18.0 & 17.0 & 56.0 & 23.5 & 29.0 \\
\hline $\mathrm{CaO} 3000$ & 7.8 & 36.0 & 9.5 & 12.5 & 46.8 & 15.3 & 28.5 \\
\hline $\mathrm{CaO} 4000$ & 7.0 & 20.3 & 7.8 & 11.8 & 30.5 & 7.8 & 17.8 \\
\hline SED & $4.00 * * *$ & $14.21^{* * *}$ & $7.94 * * *$ & $6.83^{* * *}$ & $10.59 * * *$ & $4.15^{* * *}$ & $7.43^{* * *}$ \\
\hline
\end{tabular}

ALOMY, Alopecurus myosuroides; MATCH, Matricaria chamomilla; RAPRA, Raphanus raphanistrum; AMARE, Amaranthus retroflexus; ECHCG, Echinochloa crus-galli; POLCO, Fallopia convolvulus; SETVI, Setaria viridis.

***Significant at $P<0.001$ ( $F$-test).

$93 \%$ to $96 \%$ when treated with steam $+4000 \mathrm{~kg} \mathrm{ha}^{-1}$ $\mathrm{KOH}$ vs. $75 \%$ to $91 \%$ for the corresponding rate of $\mathrm{CaO}$ (Table 5). Spring annuals showed a more pronounced species-specific response to treatments: at the highest application rate, $A$. retroflexus, $F$. convolvulus and $S$. viridis were better controlled by $\mathrm{CaO}$ than $\mathrm{KOH}$ (emergence reduction of $83 \%$ vs. $68 \%, 91 \%$ vs. $83 \%$ and $78 \%$ vs. $73 \%$ respectively), whereas E. crus-galli showed the opposite behaviour ( $66 \%$ vs. $80 \%$ ).

These results were largely confirmed by the two-way (compound $\times$ rate) analysis of variance, which showed a stronger effect of $\mathrm{KOH}$ than $\mathrm{CaO}$ on winter annuals (Table 6), whereas for spring annuals the compound effect was significant only for $A$. retroflexus $(\mathrm{CaO}>$ $\mathrm{KOH})$. The application rate effect was significant for all the seven weed species, with the two higher rates $(3000$ and $\left.4000 \mathrm{~kg} \mathrm{ha}^{-1}\right)$ that always reduced $(P<0.05)$ seedling emergence compared with the $1000 \mathrm{~kg} \mathrm{ha}^{-1}$ rate (on average by $42 \%$ and $63 \%$ respectively). A compound $\times$ rate interaction $(P<0.05)$ was found only for $R$. raphanistrum.

Linear regression analyses (Figs 2 and 3) showed a strong negative relationship between compound rate and seedling emergence, which was stronger for $\mathrm{KOH}$ in $A$. retroflexus and $S$. viridis, for $\mathrm{CaO}$ in $R$. raphanistrum, E. crus-galli and $F$. convolvulus, and comparable between the two compounds in A. myosuroides and M. chamomilla. Regression equations show that for any additional $100 \mathrm{~kg}$ of activating compound, seedling emergence was reduced by a quantity ranging between $0.3 \%$ and $2 \%$,

Table 6 Final percentage seedling emergence of the seven weed species after soil steaming with addition of two activating compounds (KOH and $\mathrm{CaO}$ ) at four rates (1000 to $4000 \mathrm{~kg} \mathrm{ha}^{-1}$ ) in the controlled environment experiment. Compound and rate mean effects and two-way ANOVA results

\begin{tabular}{|c|c|c|c|c|c|c|c|}
\hline Factor & ALOMY & MATCH & RAPRA & AMARE & $\mathrm{ECHCG}$ & POLCO & SETVI \\
\hline \multicolumn{8}{|l|}{ Compound (C) } \\
\hline $\mathrm{KOH}$ & 7.3 & 18.6 & 12.3 & 31.1 & 49.3 & 20.7 & 31.0 \\
\hline $\mathrm{CaO}$ & 10.7 & 37.5 & 19.1 & 16.2 & 51.6 & 18.3 & 29.5 \\
\hline SED (d.f. = 24) & $0.84^{* * *}$ & $3.72 * * *$ & $1.93^{* *}$ & $2.89 * * *$ & 6.03 NS & $2.17 \mathrm{NS}$ & $3.82 \mathrm{NS}$ \\
\hline \multicolumn{8}{|l|}{ Rate $\left(\mathrm{R}, \mathrm{kg} \mathrm{ha}{ }^{-1}\right)$} \\
\hline 1000 & 13.3 & 43.1 & 32.6 & 36.8 & 73.6 & 26.6 & 41.1 \\
\hline 2000 & 10.5 & 33.8 & 14.3 & 22.0 & 56.0 & 23.1 & 31.5 \\
\hline 3000 & 6.6 & 23.5 & 9.1 & 18.8 & 48.3 & 17.0 & 28.6 \\
\hline 4000 & 5.5 & 11.8 & 6.9 & 17.1 & 24.0 & 11.1 & 19.8 \\
\hline SED (d.f. = 24) & $1.19 * * *$ & $5.25 * * *$ & $2.74 * * *$ & $4.09 * * *$ & $8.53 * * *$ & $3.06 * * *$ & $5.30 * *$ \\
\hline $\mathrm{C} \times \mathrm{R}$ & NS & NS & $3.868^{*}$ & NS & NS & NS & NS \\
\hline
\end{tabular}

ALOMY, Alopecurus myosuroides; MATCH, Matricaria chamomilla; RAPRA, Raphanus raphanistrum; AMARE, Amaranthus retroflexus; ECHCG, Echinochloa crus-galli; POLCO, Fallopia convolvulus; SETVI, Setaria viridis; NS, not significant.

*** and ***Significant at $P<0.05,0.01$ and 0.001 respectively $(F$-test). 

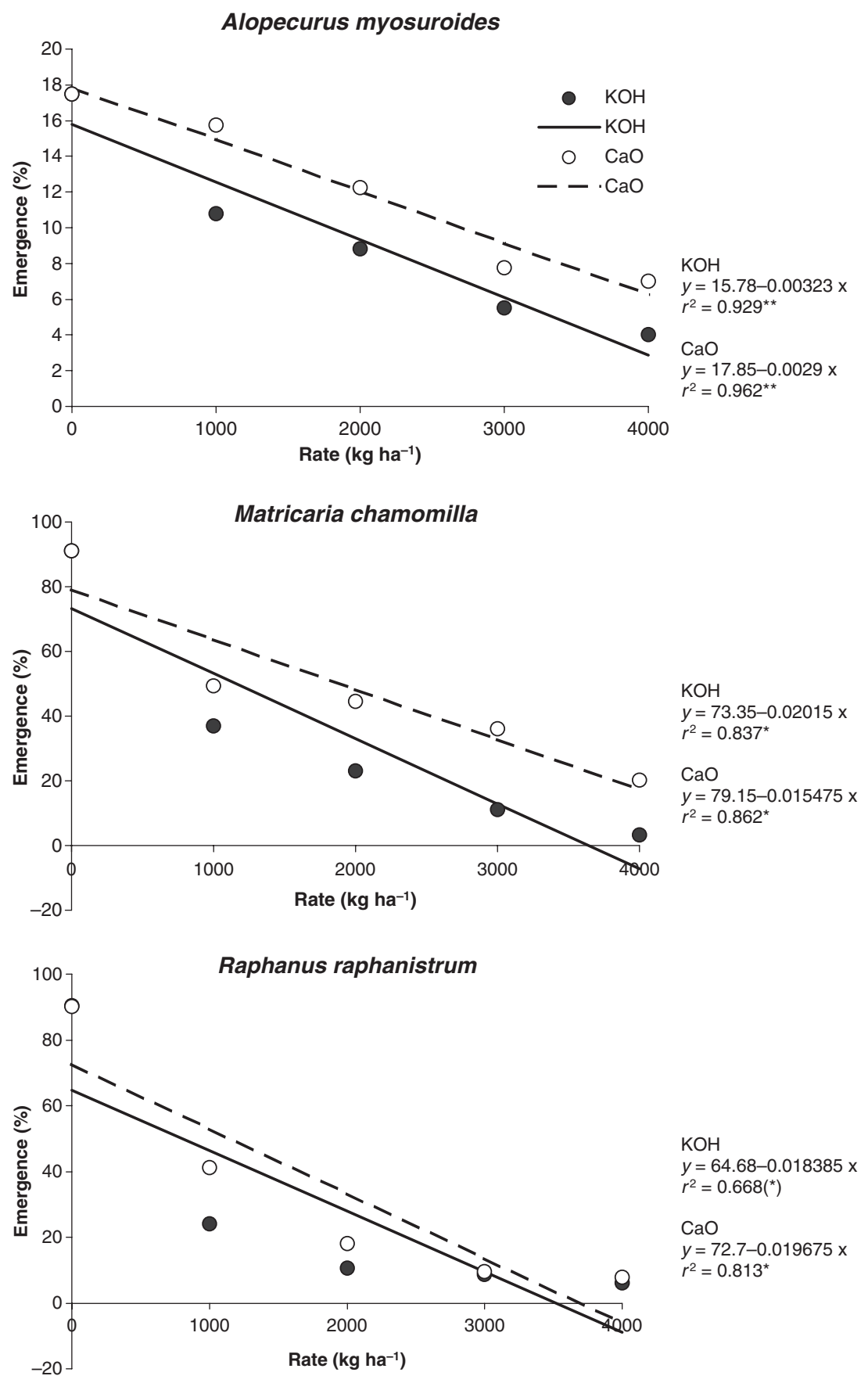

$\mathrm{KOH}$ $y=64.68-0.018385 x$ $r^{2}=0.668\left(^{*}\right)$

$\mathrm{CaO}$ $y=72.7-0.019675 x$

Fig. 2 Regression lines of per cent seedling emergence of the three winter annuals on activating compound $(\mathrm{KOH}$ or $\mathrm{CaO})$ rate, and corresponding equations and $r^{2}$ values. $\left({ }^{*}\right),{ }^{*}$ and ${ }^{* *}$ Significant at $P<0.1,0.05$ and 0.01 respectively.

A. myosuroides being the least sensitive species $(-0.3 \%$ for both compounds) and $R$. raphanistrum the most sensitive one $(-1.8 \%$ with $\mathrm{KOH}$ and $-2 \%$ with $\mathrm{CaO})$.

\section{Discussion}

\section{Soil temperature}

The use of activating compounds (especially $\mathrm{CaO}$ ) at high rates considerably increased the duration of high soil temperatures in both field and controlled environ- ment experiments. Little is known about the effect of maximum soil temperature and duration of heating on seed germination capacity. Horowitz et al. (1983) found that temperature varying from 45 to $65^{\circ} \mathrm{C}$ for $8-10 \mathrm{~h} \mathrm{day}^{-1}$ during a 2 to 5 week period was sufficient to significantly decrease weed seed germination. Other studies, which focused on the effects of heat from composting and mulching, demonstrated that weed seed germination decreased after 1 to 3 weeks with $T>46^{\circ} \mathrm{C}$ and that it was almost completely inhibited if temperature exceeded $c .60^{\circ} \mathrm{C}$ (Grundy et al., 1998; Nishida 

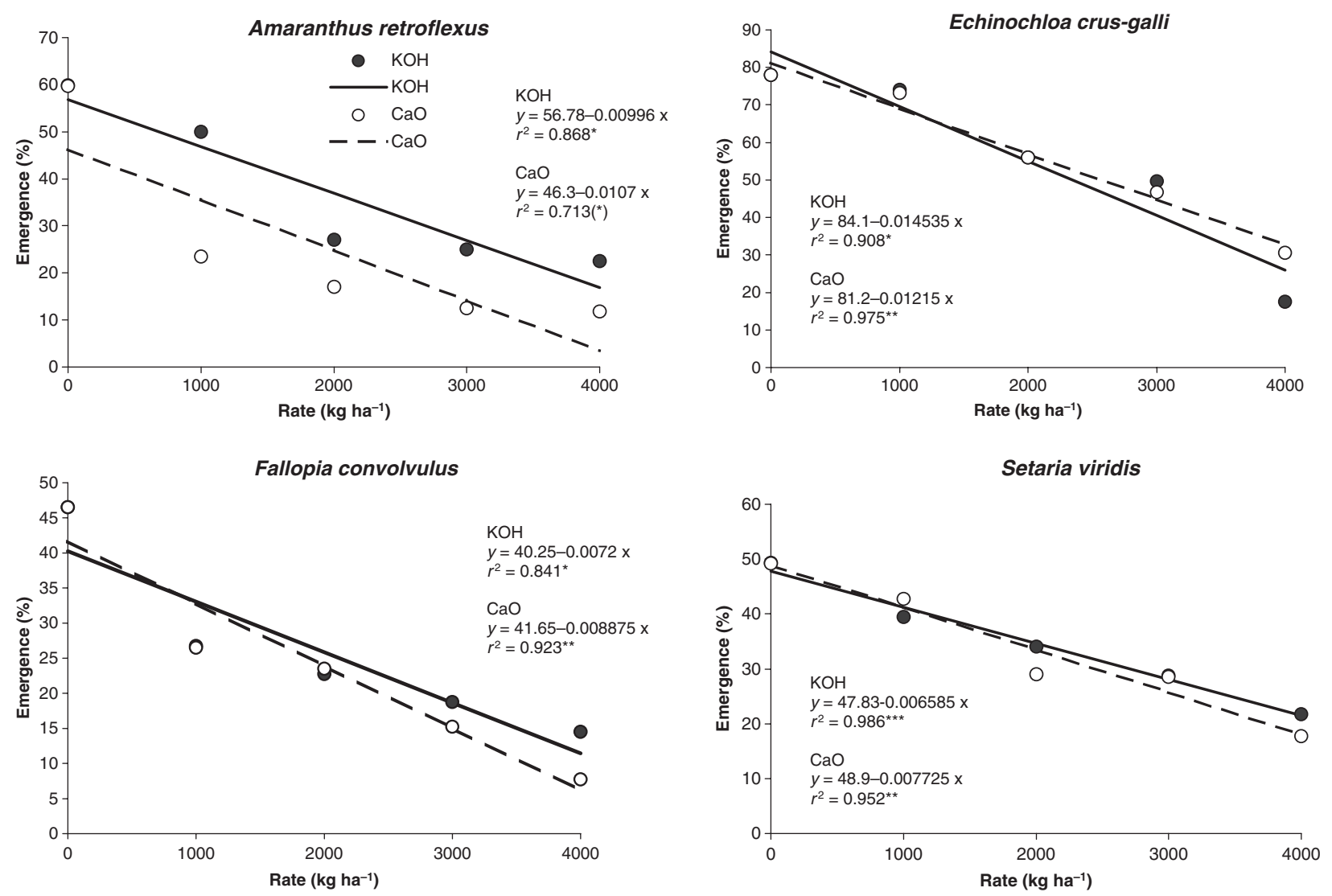

Fig. 3 Regression lines of per cent seedling emergence of the four spring annuals on activating compound $(\mathrm{KOH}$ or $\mathrm{CaO})$ rate, and corresponding equations and $r^{2}$ values. $\left({ }^{*}\right),{ }^{* * *}$ and ${ }^{* * *}$ Significant at $P<0.1,0.05,0.01$ and 0.001 respectively.

et al., 1998; Davis \& Liebman, 2003). In the case of soil steaming, the maximum soil temperature reached was found to be more important than the duration in order to decrease seed viability and it differs between species (Thompson et al., 1997). For C. bursa-pastoris, a minimum of $70^{\circ} \mathrm{C}$ is needed, while for Polygonum spp. $60^{\circ} \mathrm{C}$ is sufficient (Melander et al., 2002). Senecio vulgaris, Stellaria media and $P$. апnиa could be almost completely controlled by one steaming treatment with a maximum soil temperature $>70^{\circ} \mathrm{C}$ for a duration of 6 to $9 \mathrm{~min}$ at a depth of at least $2.5 \mathrm{~cm}$ (Bødker \& Noyé, 1994). These data indicate that all steaming treatments performed in October 2000 in this study were sufficient to cause a control effect on at least $C$. bursa-pastoris and most probably also on the other species.

In the controlled environment experiment, $\mathrm{KOH}$ reduced seedling emergence of the winter annuals A. myosuroides, $M$. chamomilla and $R$. raphanistrum to a greater extent than $\mathrm{CaO}$, despite the fact that soil temperature did not exceed $57^{\circ} \mathrm{C}$. In the field experiment, $\mathrm{KOH}$ had a stimulating effect on L. purpureum, while it suppressed $V$. hederifolia. In contrast, $\mathrm{CaO}$ had no effect on $L$. purpureum and suppressed $V$. hederifolia. In the upper seedbank layer, germination of C. bursa- pastoris was more inhibited by $\mathrm{KOH}$ than by $\mathrm{CaO}$. Although there is basically no information available on this issue, we can hypothesise that site- and speciesspecific interactions between soil and seed biological characteristics (such as thickness and hardness of the seed coat and seed size) may modulate the weed control effect exerted by increasing soil temperature and activating compounds. The activating compounds can either have a fertilisation effect and thus stimulate germination, or they can have a caustic effect, resulting in an even stronger inhibition of germination. Therefore, maximum soil temperature does not seem to be the only useful parameter for the evaluation of effectiveness of soil steaming. These results are partly in contrast with those of Melander \& Jørgensen (2005), who observed that seedling emergence decreased with maximum soil temperature according to a sigmoidal relationship.

\section{Field and controlled environment experiments}

During the sampling period (from 2 to 19 weeks after soil steaming), total field weed density did not respond to any of the treatment combinations between activating compound, application rate, and presence or absence of 
black polyethylene mulch film. This is probably the result of the opposite responses of the most abundant weed species to the activating compounds. These findings indicate that, as effects are species-specific, the choice of activating compound to be used for soil steaming has to be based on major weed species expected in the next crop. Data acquired in the controlled environment experiment, in which type and rate of the two activating compounds were tested on individual weed species, can be used to generate such guidelines.

Total per cent weed density reduction caused by the treatments with respect to the control plots varied from $11 \%$ to $48 \%$ and decreased in time. From T1 to T2 weed density doubled in all plots, but in treated plots it was on average $40 \%$ less than that in the control plots. After 4 weeks, this gap was reduced to about $20 \%$. In the first 4 weeks, the lowest reduction caused by the treatments was $16 \%$ and the highest was $63 \%$. Even though there were no significant treatment effects, even a weed density reduction of $16 \%$ in the first month after steaming could favour crop early growth and competitiveness, especially in large-seeded crops that have a higher absolute growth rate and a lower relative growth rate (RGR) than the small-seeded weed species. If weed seed germination is retarded, the crop has a better chance of shading out weeds before they can take advantage of their higher RGR (Liebman et al., 2001).

Unlike the $0-10 \mathrm{~cm}$ layer, a significant effect of the steam-alone treatment on seedbank density in the 10-20 cm layer was observed. This depended on the fact that the 'true' control had an extremely high seedbank density ( $>7300$ seedlings $\mathrm{m}^{-2}$ in the $10-20 \mathrm{~cm}$ layer), while the maximum number of seedlings emerging from the 0-10 cm layer was $4417 \mathrm{~m}^{-2}$. The number of seedlings emerging from the 10-20 cm layer (4215 seedlings $\mathrm{m}^{-2}$ ) was almost similar to that in the $0-10 \mathrm{~cm}$ layer (3800 seedling $\mathrm{m}^{-2}$ ). Laboratory trials showed a 90\% seedling emergence reduction on natural weed flora present in soil samples when maximum soil temperature was $61^{\circ} \mathrm{C}$, and a $99 \%$ reduction with a further $10^{\circ} \mathrm{C}$ temperature rise (Melander \& Jørgensen, 2005).

Activating compound effects on weed seedling densities in the two layers were similar, but were mitigated by depth. In the upper layer there was a significant compound and application rate effect and a significant interaction between the two factors. In the 10-20 cm layer only the application rate effect was significant. In both layers, weed seedling density decreased with increasing rates of activating compound. Responses of individual species were less consistent between the two layers. Heterogeneity in spatial weed seed distribution in the field increased the variability and partially masked treatment effects. However, data on the weed seedbank are clearer than those on field weed vegetation, an effect probably due to the fact that weed seedlings emergence occurred in controlled environment conditions. In contrast, higher variability in field weed emergence was likely due to additional sources of heterogeneity such as unusual rainfall pattern, seed predation, differences in soil compaction and other soil-mediated factors that cannot be controlled in a field experiment.

Results of the controlled environment experiment gave good indications about sensitivity to soil steaming of seven weed species common in the study area. A. myosuroides was the most sensitive species to the steam-alone treatment ( $77 \%$ reduction). The only other two species, the emergence of which was significantly reduced by the steam-alone treatment were $F$. convolvulus and $S$. viridis. Swedish field trials did not show a significant control effect of steaming on $F$. convolvulus, although soil temperature reached 70 to $80^{\circ} \mathrm{C}$ (Hansson $\&$ Svensson, 2004). Species sensitivity to the steam-alone treatment does not seem related to seasonality of weed emergence (winter vs. spring annuals). However, when steam was coupled with use of activating compounds, it seemed that $\mathrm{KOH}$ was more effective on winter annuals than on spring annuals. A. retroflexus was the only species for which the control effect of $\mathrm{CaO}$ was higher, as also shown by the linear regression analysis.

In general, M. chamomilla and E. crus-galli were the two species that responded less to the different treatment combinations. This is in accordance with Melander and Jørgensen (2005), who also observed a high tolerance of E. crus-galli to heat. Data from Table 5 indicate that the highest control effect (in terms of statistical significance) can be achieved even with the application of $2000 \mathrm{~kg} \mathrm{ha}^{-1}$ of activating compound in the case of $R$. raphanistrum $(\mathrm{KOH}), \quad S$. viridis $(\mathrm{KOH})$ and $A$. retroflexus (both compounds) and even $1000 \mathrm{~kg} \mathrm{ha}^{-1}$ for $A$. myosuroides (KOH). For $F$. convolvulus, at least $3000 \mathrm{~kg} \mathrm{ha}^{-1}$ of $\mathrm{CaO}$ is needed to attain the highest suppression, whereas in the case of $M$. chamomilla (KOH) and E. crus-galli (both compounds) this can be attained only when applying the highest rate. Information on species-specific sensitivity to soil steaming treatments is the key to the success of this type of intervention in real farm situations. This is true not only for weeds but also for crops, some of which, e.g. sugar beet, maize, leek, onion and partly carrot, are tolerant to heat (Melander \& Jørgensen, 2004). However, simultaneous drilling and steaming is in practice a difficult operation to carry out, because the lethal temperature gap between weeds and crop is often small and the steaming effect can differ depending on soil thermodynamic properties.

The action of the Bioflash System ${ }^{\mathrm{TM}}$ can be explained by the combined effect of steam and activating 
compounds, although soil heating is the main factor. $\mathrm{KOH}$ gave better results on weed control and slightly lower soil temperature values with respect to $\mathrm{CaO}$. Thus, a direct herbicidal effect of $\mathrm{KOH}$ can be supposed, but only in association with steam. In fact, steam is required to promote the hydration reaction of the activating compounds. No significant weed control effect is expected with the only application of $\mathrm{CaO}$ or $\mathrm{KOH}$, that are normally adopted in agriculture as fertilisers or amendments. Finally, it is important to note that the Bioflash System $^{\text {TM }}$ is also effective against soil-borne pests and diseases and that treatments are characterised by a unit application cost $\left(c .4000 € \mathrm{ha}^{-1}\right)$ lower than methyl-bromide (Peruzzi et al., 2007).

\section{Future perspectives}

Despite the fact that treatments were not always effective, especially when applied in the field, results from this study show that there are possibilities for weed control by soil steaming (especially in the first 4 weeks after treatment) when applying intermediate to high rates of activating compounds. Individual weed species exhibited different responses to type and rate of activating compound. As such, farmers will have to choose the best compound by rate combination based on the expected weeds in their crop. This study has shown that high compound rates are superfluous when more sensitive weed species are present. Little is known on the effects of activating compounds and maximum soil temperature on the beneficial soil fauna and soil chemical and physical characteristics. Companion trials are needed to investigate these effects, especially in the case of repeated applications of steaming, to generate data that could help fine-tune more environmentally sound crop production systems.

\section{References}

Ahmad Y, Hameed A \& Aslam M (1996) Effect of soil solarization on corn stalk rot. Plant and Soil 179, 17-24.

Arora A \& Yaduraju NT (1998) High-temperature effects on germination and viability of weed seeds in soil. Journal of Agronomy and Crop Science Zeitschrift Fur Acker Und Pflanzenbau 181, 35-43.

BÀrberi P \& Lo CASCIO B (2001) Long-term tillage and crop rotation effects on weed seedbank size and composition. Weed Research 41, 325-340.

Bàrberi P, Moonen AC, Raffaelli M, Peruzzi A, Belloni P \& Mainardi M (2002) Soil steaming with an innovative machine - effects on actual weed flora. In: Proceedings 2002 5th Workshop of the EWRS Working Group on Physical and Cultural Weed Control, Pisa, Italy, 238-241.

BøDKER L \& Noyé G (1994) Effekten af varmebehandling af overfladejord i nåletræssåbede over for ukrudt og rodpatogene svampe [Effect of heat treatment of surface-soil in raised seedbeds with conifers against weeds and root pathogens (with English summary)]. In: Proceedings 1994 11th Danish Plant Protection Conference/Pests and Diseases, Nyborg, Denmark, 239-248.

Chase CA, Sinclair TR \& Locascio SJ (1999) Effects of soil temperature and tuber depth on Cyperus spp. control. Weed Science 47, 467-472.

COHORT Software (2002) CoStat. COHORT Software, Monterey, CA, USA (available at: http://www.cohort.com; last accessed 16 June 2008).

Davis AS \& Liebman M (2003) Cropping system effects on giant foxtail (Setaria faberi) demography: I. Green manure and tillage timing. Weed Science 51, 919-929.

Gomez K \& Gomez A (1984) Statistical Procedures for Agricultural Research. John Wiley, New York, USA.

Grundy AC, Green JM \& Lennartsson M (1998) The effect of temperature on the viability of weed weeds in compost. Compost Science and Utilization 6, 26-33.

Habeeburrahman PV \& Hosmani MM (1996) Effect of soil solarization in summer on weed growth and yield of succeeding rainy-season sorghum (Sorghum bicolor). Indian Journal of Agronomy 41, 54-57.

HANF M (1990) Le infestanti $d$ Europa, le loro plantule, i loro semi. Edizioni Agricole BASF, Bologna, Italy.

HANSSON D \& Svensson SE (2004) Steaming soil in narrow strips for intra-row weed control in sugar beet. In: Proceedings 2004 6th EWRS Workshop on Physical and Cultural Weed Control, Øyer, Norway, 152.

Horowitz M, Regev Y \& Herzlinger G (1983) Solarization for weed control. Weed Science 31, 170-179.

Kumar B, Yaduraju NT, Ahuja KN \& Prasad D (1993) Effect of soil solarization on weeds and nematodes under tropical Indian conditions. Weed Research 33, 423-429.

Liebman M, Mohler CL \& Staver CP (2001) Ecological Management of Agricultural Weeds. Cambridge University Press, Cambridge, UK.

Melander B \& Jørgensen MH (2004) Recent results in the development of band steaming for intra-row weed control. In: Proceedings 2004 6th EWRS Workshop on Physical and Cultural Weed Control, Øyer, Norway, 154.

Melander B \& Jørgensen MH (2005) Soil steaming to reduce intrarow weed seedling emergence. Weed Research 45, 202211.

Melander B, Heisel T \& Jørgensen MH (2002) Bandsteaming for intra-row weed control. In: Proceedings 2002 5th EWRS Workshop on Physical and Cultural Weed Control, Pisa, Italy, 216-219.

Moonen AC \& BÀrberi P (2004) Size and composition of the weed seedbank after 7 years of different cover-crop-maize management systems. Weed Research 44, 163-177.

Nishida T, Shimizu N, Ishida M, Onoue T \& Harishima N (1998) Effect of cattle digestion and of composting heat on weed seeds. Japan Agricultural Research Quarterly 32, 55-60.

Peruzzi A, Raffaelli M, Ginanni M \& Mainardi M (2002) Development of innovative machines for soil disinfection by means of steam and substances in exothermic reaction. In: Proceedings 2002 5th EWRS Workshop on Physical and Cultural Weed Control, Pisa, Italy, 220-229.

Peruzzi A, Borelli M, Mazzoncini M, Raffaelli M, GinANni M \& BÀrberi P (2004) Weed seeds control by steam and substances in exothermic reaction. In: Proceedings 
2004 6th EWRS Workshop on Physical and Cultural Weed Control, Øyer, Norway, 155-165.

Peruzzi A, Raffaelli M, Ginanni M, Lulli L, Fontanelli M \& Frasconi C (2007) Una operatrice semovente innovativa per la disinfezione del terreno con vapore e sostanze a reazione esotermica. In: Proceedings 2007 of the Conference: "Vapore dacqua e sostanze a reazione esotermica per la geodisinfezione a basso impatto ambientale: una possibile alternativa all'impiego del bromuro di metile", Pisa, Italy, $31-48$.

Raffaelli M, Peruzzi A, Del Sarto R, Mainardi M, Pulga L \& PAnnocchia A (2002) Effetto del vapore e di sostanze a reazione esotermiche sul riscaldamento del terreno: risultati di un quadriennio di sperimentazione. In: Vapor dacqua e sostanze a reazione esothermica: una combinazione a risotto impatto ambientale per la disifezioen e la disinfestazione del terreno, Forli, Italy, 45-52.

Ricci MSF, De Almeida DL, Ribeiro RDD et al. (1999)

Cyperus rotundus control by solarization. Biological Agriculture and Horticulture 17, 151-157.
SAuerborn J, Linke KH, SAXena MC \& Koch W (1989) Solarization - a physical control method for weeds and parasitic plants (Orobanche spp.) in Mediterranean agriculture. Weed Research 29, 391-397.

TESI R (2001) Colture protette: ortoflorovivaismo. Calderini Edagricole, Bologna, Italy.

Thompson AJ, Jones NE \& Blair AM (1997) The effect of temperature on viability of imbibed weed seeds. Annals of Applied Biology 130, 123-134.

Triolo E \& D'ERrico FP (2002) Il vapor d'acqua: un secolo di esperienza per un sistema fitoiatrico attuale. In: Proceedings 2002 of the Conference "Vapor dacqua e sostanze a reazione esotermica: una combinazione a ridotto impatto ambientale per la disinfezione e la disinfestazione del terreno", Forli, Italy, 11-17.

Viggiani P \& ANGELINi R (1998) Erbe spontanee e infestanti: tecniche di riconoscimento (Graminaceae). Bayer, Milan, Italy. 